\title{
Traces and Representations of the U.S.-Mexico Frontera
}

\begin{abstract}
The following was the author's presidential address at the annual meeting of the Pacific Coast Branch, American Historical Association, in Northridge, California, on August 4, 2017. The twentieth-century visual history of the U.S.-Mexico borderlands, la frontera, offers a rich set of representations of the shared border environments. Photographs, distributed in the United States and in Mexico, allow us to trace emerging ideas about the border region and the politicized borderline. This essay explores two border visualization projects-one centered on the Mexican Revolution and the visual vocabulary of the Mexican nation and the other on the repeat photography of plant ecologists-that illustrate the simultaneous instability and power of borders. KEYWORDS U.S.-Mexico border, boundary monuments, Mexican Revolution, repeat photography, Robert R. Humphrey
\end{abstract}

Let's start with two frontera portraits. The first might be familiar to you.

Frida Kahlo's Self Portrait along the Border Line between Mexico and the United States/Autorretrato en la frontera entre México y los Estados Unidos, 1932, is a striking image. Holding the Mexican flag and a cigarette, Kahlo surrounds herself with iconography of two nations. On the left side of the self-portrait, her depiction of pre-Columbian figurines, scattered on the ground in front of a temple, are in tune with the Mexican nationalism project that turned to its indigenous Aztec and Inca past to assert its heritage and power. On the right, the U.S. flag is enveloped in smoke emanating from industrial stacks, labeled FORD, in front of a towering cityscape. Below, black electrical wires snake into the underground, as a parallel to the white-rooted vegetation on the Mexican side. Interpretations of this divided portrait abound. ${ }^{1}$

I. A few examples: Hayden Herrera, Frida: A Biography of Frida Kablo (New York: Harper \& Row, I983), I52-54; Janice Helland, "Aztec Imagery in Frida Kahlo's Paintings," Woman's Art Journal II (Fall 1990/Winter 199I): 8-I3; Nancy Deffenbach, Maria Izquierdo and Frida Kablo: Challenging Visions in Modern Mexican Art (Austin: University of Texas Press, 2015), 74-76.

Pacific Historical Review, Vol. 87, Number I, pps. I50-I72. ISSN 0030-8684, electronic ISSN I5338584 (c) 2018 by the Pacific Coast Branch, American Historical Association. All rights reserved. Please direct all requests for permission to photocopy or reproduce article content through the University of California Press's Reprints and Permissions web page, http://www.ucpress.edu/ journals.php?p=reprints. DOI: https://doi.org/IO.I525/phr.20I8.87.I.I50. 


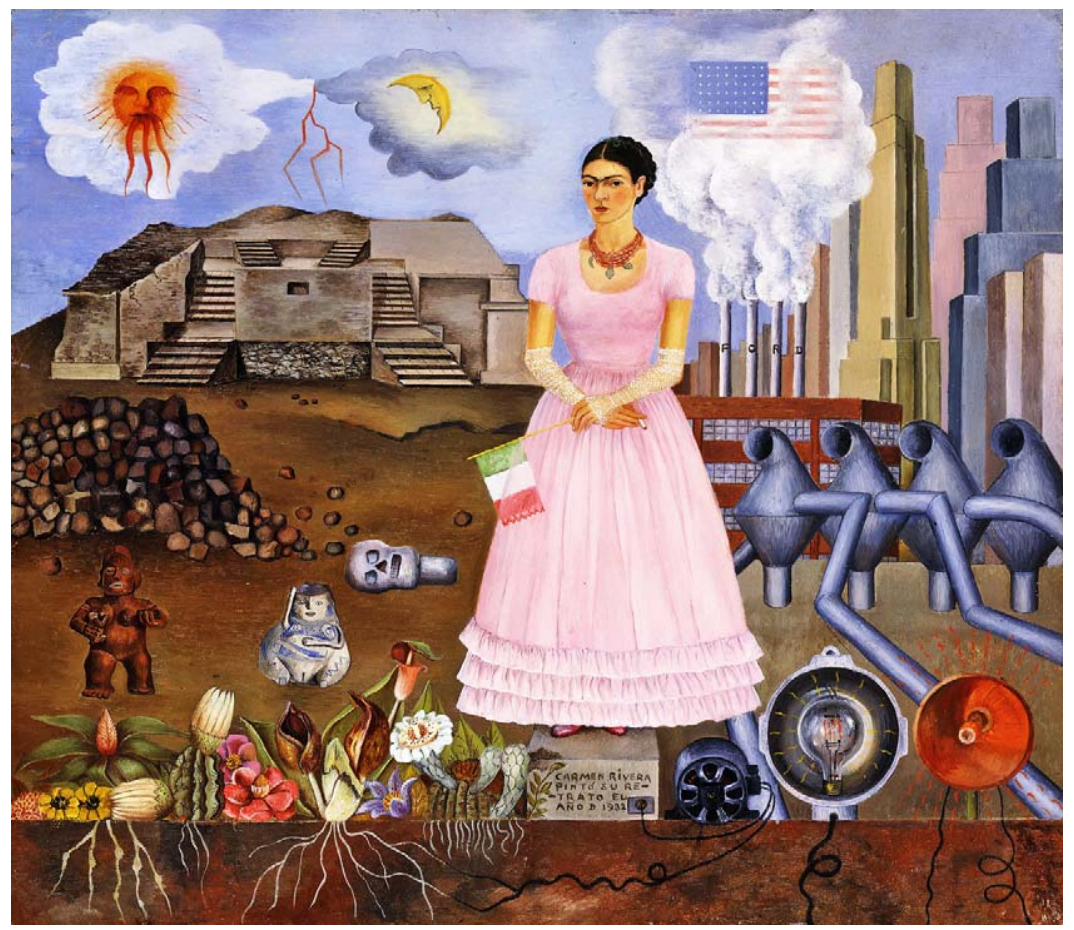

FIGURE 1. Frida Kahlo, Self-Portrait on the Borderline of Mexico and the United States, 1932. Banco de México Diego Rivera Frida Kahlo Museums Trust, Mexico, D.F. / Artists Rights Society (ARS), New York.

It is a personal portrait-painted by a young woman at twenty-five, in the United States with her husband Diego Rivera, who was completing commissioned murals in Detroit and New York. Photographs of Kahlo in the act of painting this portrait-posed with Rivera or on her own-remind us of the multiple intended audiences of the work. ${ }^{2}$ A cultural and political painting, it is also a borderline portrait. Take a look at where she is standing: on a boundary stone that marks the border between Mexico and the United States. Echoing the language carved into the boundary monuments, the stone is inscribed "Carmen Rivera painted her portrait in I932."3

You are less likely to be familiar with this second portrait-Robert "Bob" Humphrey in I935, also depicted in the U.S.-Mexico frontera. His arms

2. These photographs are in the Museum Archives, Detroit Institute of Arts; Linda Banks Downs, Diego Rivera: The Detroit Industry Murals (New York: WW Norton, I999); Diego Rivera \& Frida Kablo in Detroit, Detroit Art Institute exhibit, 2015.

3. Her Christian name and her husband's last name. 


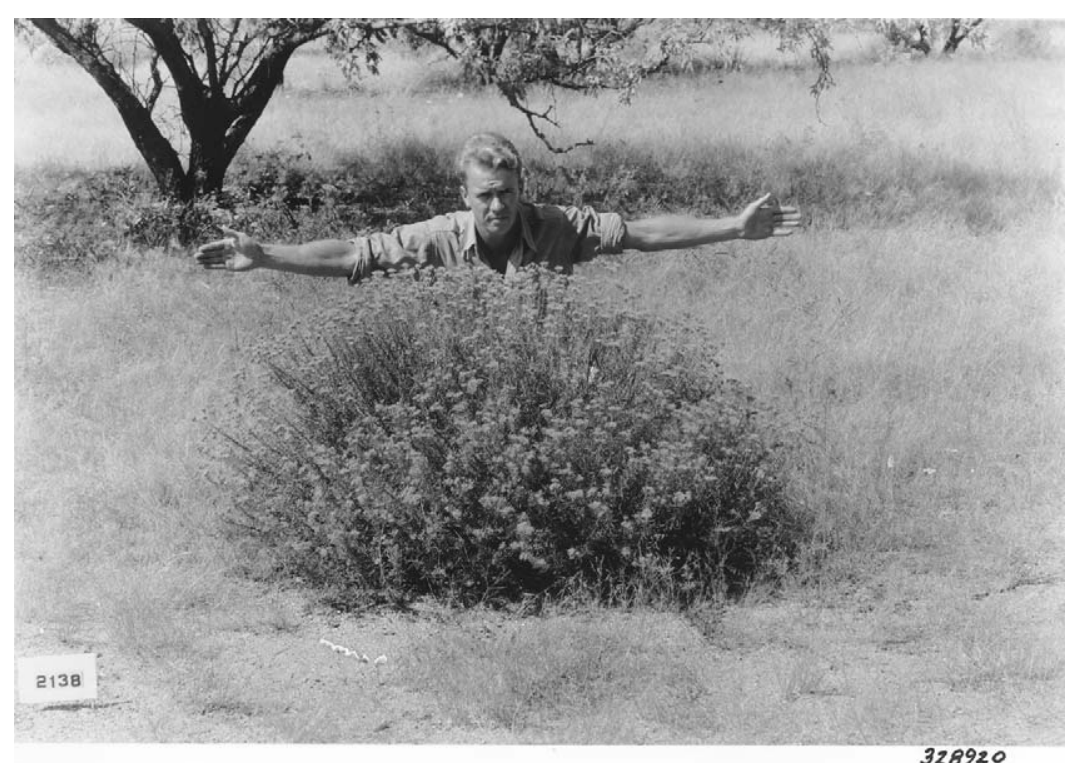

328920

FIGURE 2. Robert Humphrey and a burroweed plant (Isocoma tenuisecta), I935, Santa Rita Experimental Range Long-term Transect and Spatial Data, SRER Long-term Data and Maps-University of Arizona. <https://cals.arizona.edu/ srer/data.html> Courtesy of Santa Rita Experimental Range Digital Database.

stretched wide, he is ostensibly serving as a human measuring stick for the arid lands bush-burroweed - that is the subject of his investigation. A plant ecologist who crisscrossed the borderlands through his long career, Humphrey took numerous photographs of the borderline-or more accurately of the vegetation surrounding the border monuments that represent the international boundary. He did so as a measure - to study vegetative change over time by comparing earlier photographs with his matching re-photographs, taken systematically in the I940s, the I950s, the I960s, and the I980s. This image, too, is a personal portrait but also a cultural and scientific onea borderline image. Another of Humphrey's repeat photographs, also using the human form as a measure, makes the point more directly. Taken in the I980s and showing border patrolman Joe Brewster standing on the base of a boundary monument, the image unintentionally echoes Kahlo's similar positioning.

The I980s image is included in Humphrey's published book, 90 Years and 535 Miles: Vegetation Changes along the Mexican Border, alongside, and in intended comparison to, an image photographed in the same spot in the 


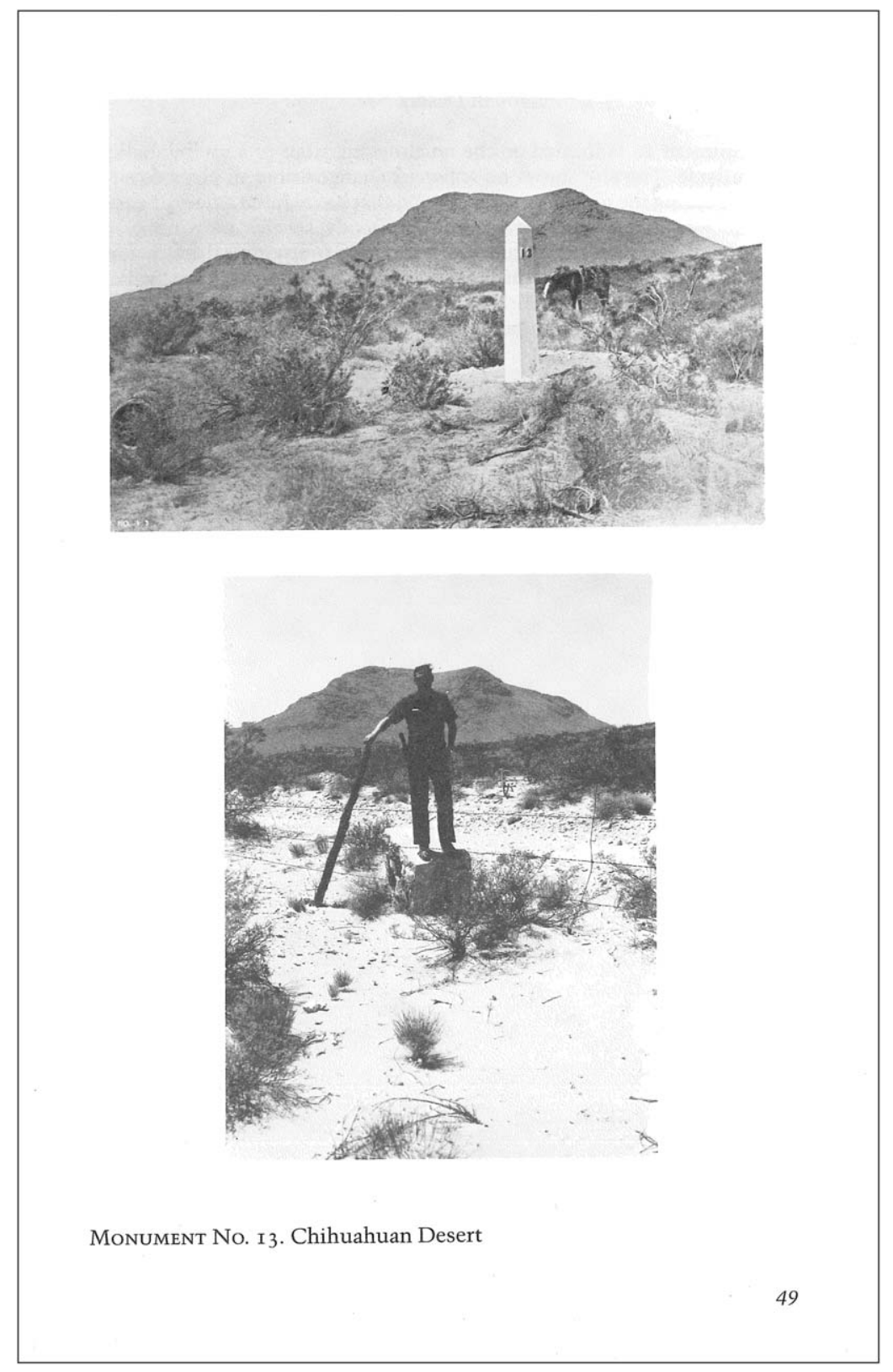

FIGURE 3. Robert R. Humphrey, 90 Years and 535 Miles: Vegetative Change Along the Mexican Border (Albuquerque: University of New Mexico Press, 1987), p. 49. 
I89os. ${ }^{4}$ Humphrey drew on a particular baseline: individual photographs of obelisks along the U.S.-Mexico border taken when the line of 258 border monuments were set as part of the I89I-I896 International Boundary Commission resurvey of the U.S.-Mexico border. Two official members of the resurvey, Mexican topographer and photographer Luis Servín and U.S. photographer Daniel Payne, used their cameras to situate the monuments within the landscape. ${ }^{5}$ Now ninety years later, Humphrey used their work and the border monuments to situate ecological changes within the landscape.

As this pairing of borderline portraits suggest, there are multiple meanings encoded in representations of the U.S.-Mexico border. The two I930s images speak to the distinct perspectives on the borderline-ones in which their creators attempt to communicate through a visual vocabulary. And they are ones whose meanings have changed over time for distinct audiences. The visual history of the U.S.-Mexico borderlands, la frontera, offers a rich set of such representations of the shared border environments in both Mexico and the United States. Among the numerous representations that have been crafted and distributed through the long twentieth century are those that allow us to trace emerging ideas about the border region and the politicized borderline.

As part of my current work, I have been analyzing "borderline visualization projects" established during the twentieth century-efforts, sometimes deliberate, sometimes less consciously, within la frontera to measure, mark, and visually represent the meanings of the border. These particular sets of images/photographs are ones that offer the opportunity to situate them in their own historical moment of creation as well as to examine their multiple uses through time in both the U.S. and Mexico. As traces and representations of the U.S.-Mexico frontera, these works engage cultural meanings and inform contemporary conversations. To trace the track or path, to find or discover by investigation, to copy a map or image by drawing over its lines on a superimposed piece of transparent paper, these are familiar definitions.

4. Robert R. Humphrey, 90 Years and 535 Miles: Vegetation Changes along the Mexican Border (Albuquerque: University of New Mexico Press, 1987), 49.

5. Vistas de los Monumentos á lo largo de la línea divisoria entre México y los Estados Unidos de El Paso al Pacifico, vol. III of Memoria de la Sección Mexicanade la Comisión Internacional de Limites entre México y los Estados Unidos que restableció los monumentos de El Paso al Pacifico; bajo la dirección de México del ingeniero Jacobo Blanco, jefe de la Comisión Mexicana (New York: J. Polhemus y Compania, I90I); Katherine G. Morrissey, "Monuments, Photographs and Maps: Visualizing the U.S.-Mexico Border in the I89os," in Border Spaces: Visualizing the U.S.-Mexico Frontera, eds. Katherine G. Morrissey and John-Michael H. Warner (Tucson: University of Arizona Press, 20I8). 


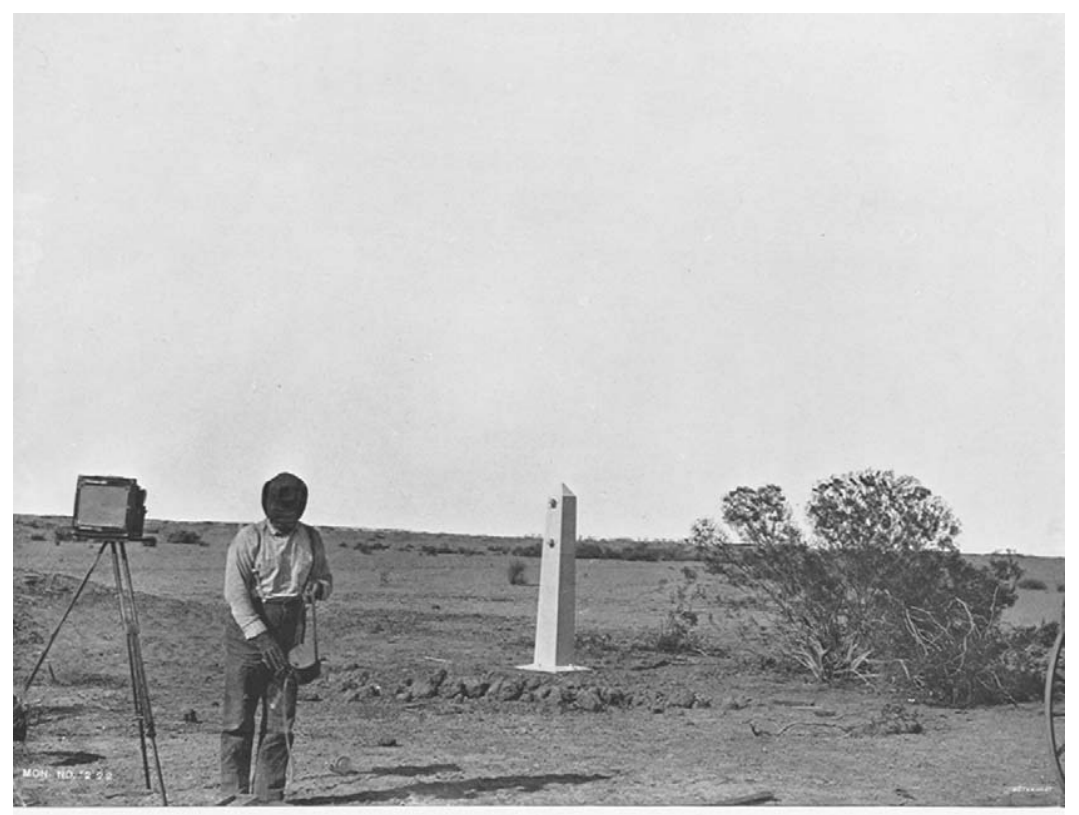

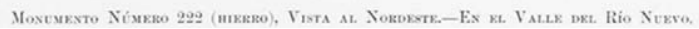

FIgURE 4. Monument No. 222. Report of the Boundary Commission upon the Survey and Re-marking of the Boundary between the United States and Mexico west of the Rio Grande, I89I to I896, Album (Washington, DC: GPO, I899). Courtesy of University of Arizona Libraries, Special Collections.

There is also the "trace," that lingering presence, which, to use its linguistic meaning, confirms the absence of a presence. Now I'm not going to delve too deeply into Jacques Derrida, but his theoretical construct is helpful as we consider the inevitable non-meaning-the immaterial silent associations, if you will—of the border that are brought to mind along with meaning. ${ }^{6}$

To underscore this point - that is, the conjoined abstract and material essence of border-we might turn as well to the mathematical meaning of "trace." In linear algebra, that branch of mathematics concerned with vector spaces and linear mapping, useful in cartography, trace is the sum of the diagonal elements in a matrix - a line, one that might be represented on a map with the word "frontera." The trace divides two quadrants-north and south, if you will. It enables triangulations and comparisons in a complex

6. Jacques Derrida, “Différance,” Margins of Philosophy, trans. Alan Bass (Chicago: University of Chicago Press, 1982), 3-27, included in Mark C. Taylor, Deconstruction in Context: Literature and Philosophy (Chicago: University of Chicago Press, 1986), 396-420. 
vector space. And la frontera is a complex vector space indeed. ${ }^{7}$ To illustrate, let's take two quick visual journeys: one centered on the Mexican Revolution and the visual vocabulary of the Mexican nation and the other centered on the perspective of plant ecologists, exemplified by Humphrey's visualization project. ${ }^{8}$

The Mexican Revolution, stretching through the second decade of the twentieth century, is well recognized as one of the first conflicts heavily documented by photographers and photojournalists. ${ }^{9}$ And the action along and near Mexico's northern border, with its relatively free access, drew especial attention in the United States. From the first battle of Ciudad Juárez, across from El Paso, in May I9II, to the second and the third battles, amateurs and professionals employed their cameras to depict and share a narrative of current events. ${ }^{10}$ The border scene there and elsewhere-in border towns of Naco, Douglas, Agua Prieta, Nogales, and Columbus; in northern states of Chihuahua and Sonora-became familiar representations of the broader conflicts and unrest, especially where those images circulated. For audiences in the United States, the images could be seen in picture postcards, newsreels, magazines, and newspapers. The proximity to the United States, the centrality of northern Mexico for revolutionary movements, and the increasingly militarized border all brought heightened awareness of la frontera.

7. My thanks to Leticia Abad for helping me think through these issues and to the participants of the 2017 National Endowment of the Humanities Borderlands Summer Seminar at the Newberry Library led by Benjamin Johnson.

8. My evaluation of the Mexican Revolution photographs is based on my ongoing review of archival photograph collections, especially from Border Heritage Collection, El Paso Public Library; El Paso Historical Society; Special Collections, University of Texas, El Paso; Harry Ransom Center, University of Texas, Austin; Briscoe Center for American History, University of Texas, Austin; Beinecke Rare Book and Manuscript Library, Yale University, New Haven, Conn.; Newberry Library, Chicago; Bancroft Library, University of California, Berkeley; Archives and Special Collections, New Mexico State University, Las Cruces; Special Collections, University of Arizona Libraries, Tucson; Arizona Historical Society, Tucson; Pimería Alta Historical Society, Nogales, Arizona; National Archives at College Park, Md.; Prints and Photographs Division, Library of Congress, Washington, D.C.; Fototeca, Archivo General de la Nación, Mexico City; Fototeca Nacional del Instituto Nacional de Antropología e Historia, Pachuca, Mexico.

9. Zuzana M. Pick, Constructing the Image of the Mexican Revolution: Cinema and the Archive (Austin: University of Texas Press, 2010); Mexico at the Hour of Combat: Sabino Osuna's Photographs of the Mexican Revolution, ed. Ronald H. Chilcote (Laguna Beach, Cal.: Laguna Wilderness Press, 20I2).

Io. Miguel Ángel Berumen, I9II, La batalla de Ciudad Juárez, I. La Historia, II. Las Imagenes (Ciudad Juárez, Chih, Mexico: Berumen y Muñoz editores, Cuadro por Cuadro, 2003). 


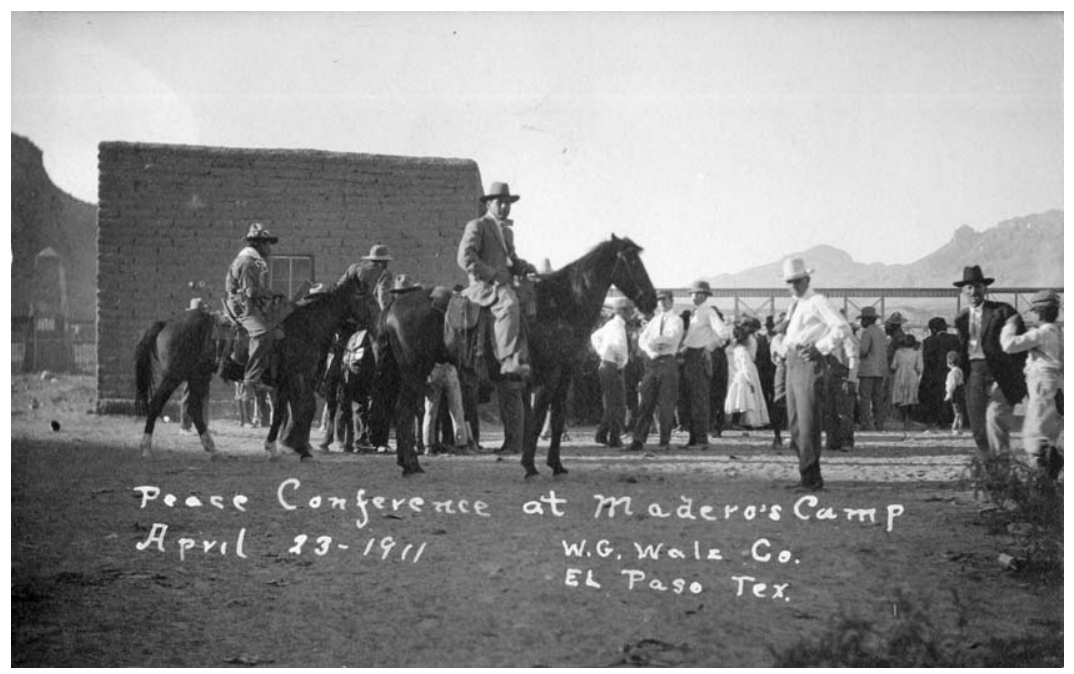

FIgure 5. "Peace Conference at Madero’s Camp," i9ii, \#26,oo6, Out-of-StateTexas-El Paso, PC 98, Photo Postcard Collection, Arizona Historical Society Library, Tucson.

To tell the visual story of the Mexican Revolution for an American audience meant to mark the line between the United States and Mexico in any number of ways. While some who wielded cameras, like British photojournalist Jimmy Hare sent by Collier's magazine, had experience in combat photography, most did not, and they often relied on the aesthetic derived from studio photography and picture postcards-the posed shot, whether of soldiers in the field or the aftermath of battle. ${ }^{11}$

In these emerging narratives, the borderline and its border monuments served as one of the effective tropes. In I9II, for example, revolutionary leader Francisco Madero's camp outside El Paso/Juárez surrounded boundary monument number I. And with his headquarters (Casa Adobe) nearby, visitors and photographers from El Paso came to view the camp and the monument as well. They did so with Madero's encouragement-at least fourteen photographers showed up in late April I9II to memorialize a meeting of the revolutionary junta. ${ }^{12}$ They also pointed their cameras in other directions.

II. Cecil Carnes, Jimmy Hare News Photographer, Half a Century with a Camera (New York: Macmillian \& Co., I940), 20I-I5; Lewis L. Gould and Richard Greffe, Photojournalist: The Career of Jimmy Hare (Austin: University of Texas Press, I977), 74-75.

I2. David Dorado Romo, Ringside Seat to the Revolution: An Underground Cultural History of El Paso, I893-I923 (El Paso, Tex.: Cinco Puntos Press, 2005); Beruman, I9II, Las Imagenes, 6I-63. 
Whether they intentionally framed their images with the boundary monument, or inadvertently captured the familiar obelisk on film, their photographs began to circulate widely. For savvy commercial distributors as well as their retail audiences, such markers helped present the visual narrative of the border conflicts. ${ }^{13}$

And when the border monuments were not in view, other markers stood in for them-the close attention to the border can be seen in the lines drawn on and words added to and re-inscribed on the negatives and prints. Some photographers, like Cal Osbon working out of Douglas, Arizona, wrote prolific comments directly on their images. On postcards, senders too drew lines and arrows to depict the borderline and added words to distinguish the U.S. side from the Mexican side. Even without such textual additions, however, an implied borderline became referenced visually. Composite postcards, for example, juxtaposed two images: one of a U.S. military camp and the other of a Mexican adobe village, perhaps, or one of "U.S. troops on the Rio Grande watching the Mexican side" contrasted with the other of "Refugees at the border awaiting admission to the U.S." A conditioned American audience knew how to read this combination of photos divided by lines; such viewers would see a borderline and its national intents. The border monuments and the borderline-implied or visiblebecame part of the coded language that marked sets of meanings and pinned them to place.

Local commercial photographers (such as Albert W. Lohn of Nogales or D.W. Hoffman of El Paso) capitalized on an emerging military market with such picture postcards. The presence of U.S. troops increased dramatically in the region during the Mexican Revolution years. While some units crossed the border as part of the 1916 Pershing Expedition, most others remained in camps and at forts, in patrols and training, along the U.S. side of the line. Regular military personnel, including segregated African American units, were joined by National Guard troops, deployed from around the country, to constitute a substantial occupation force. At Camp Stephen D. Little, for example, outside of Nogales, guardsmen from Pennsylvania, Alabama, Utah, California, Connecticut, and Idaho units crowded into tents arrayed along the terraced bluffs.

I3. For another example, H.H. Stratton, "On the Mexican Border, Mexican Fighters in Their Trenches," folder II, WA Photos 307, Postcard Photographs Collection, Yale Collection of Western Americana, Beinecke Rare Book and Manuscript Library. 


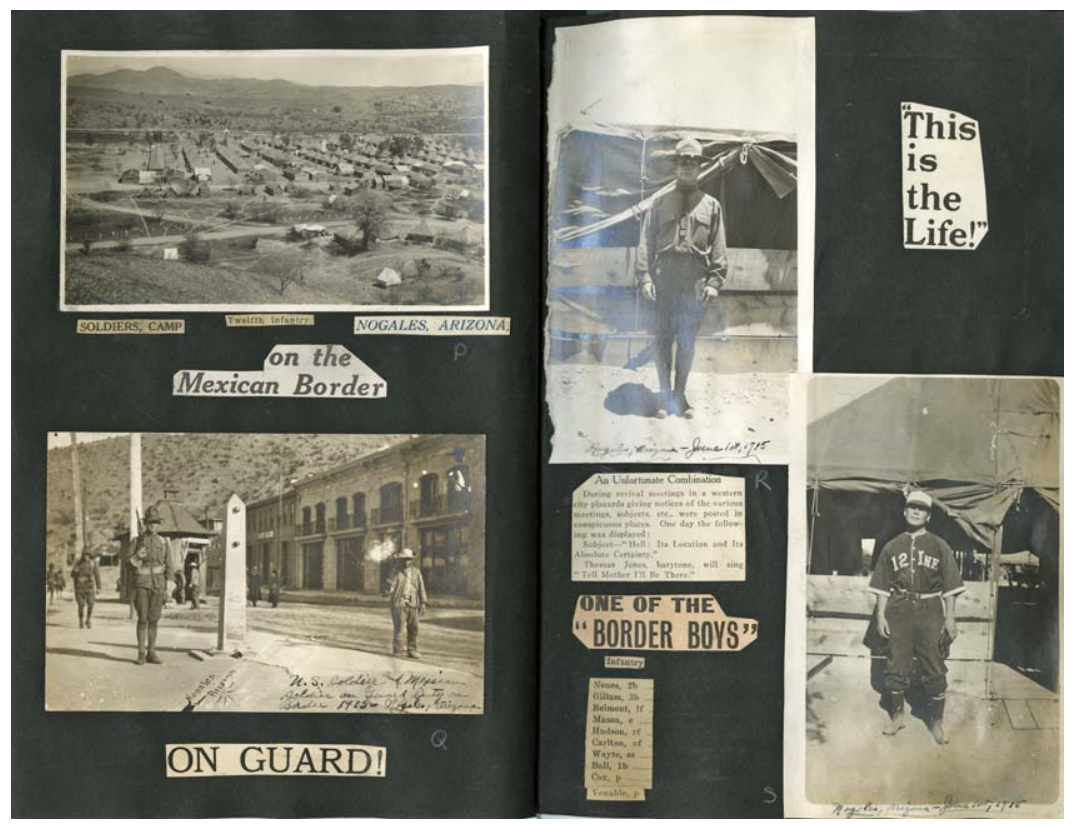

FIGURe 6. "On the Mexican Border," Album 3, PC 201, Harold C. Wayte Photograph Collection, Arizona Historical Society Library, Tucson.

Iconic images of soldiers and monuments, marking the boundary line with white, black, and brown military men and adding descriptive words to the negatives, entered the market from border towns. Within the United States, such symbolic postcards found their way into homes across the nation, inscribed with individualized messages scribbled on both front and back. ${ }^{14}$ Widely circulated, commercially produced, and privately consumed, these photographic postcards frequently ended up in photo albums and scrapbooks, alongside snapshots taken by the soldiers themselves. The exuberant twenty-year-old Harold C. Wayte, stationed at Camp Nogales, Arizona, as soldier in the I 2 th Infantry, for example, was "one of the "border boys," as he emphasized with snapshots of himself in military and baseball uniforms. In direct comparison, he pasted in a popular picture postcard depicting, as he

I4. Paul J. Vanderwood and Frank N. Samponaro, Border Fury: A Picture Postcard Record of Mexico's Revolution and U.S. War Preparedness, 19IO-I9I7 (Albuquerque: University of New Mexico Press, 1988); Daniel D. Arreola, Postcards from the Rio Bravo Border (Austin: University of Texas Press, 2013); Arreola, Postcards from the Sonora Border: Visualizing Place through a Popular Lens (Tucson: University of Arizona Press, 2017); Luc Sante, Folk Photography: The American RealPhoto Postcard, 1905-1930 (Portland, Ore.: YETI Books, 2009). 
tells us, a "U.S. soldier and Mexican soldier on guard duty on border in 1915" on opposite sides of border monument 22 in Nogales. ${ }^{15}$

Such mementos introduced the border region, and boundary monuments, to their familial audiences within the context of personal experiences and prejudices. With added commentary and descriptions on photographs and postcards, senders' notes reflected the casual racial prejudices of the time. The annotated postcards mediated the news emerging from increased national involvement in international conflicts, linking the personal to the political. Among the borderline postcards frequently sent was a staged shot that offered a popular gag: "A U.S. soldier and his ass in Mexico." In versions created by several photographers, a soldier is posed next to a border marker, with his donkey or mule positioned half across the border. The racist humor and visual jabs sharpened the line. ${ }^{16}$

On both sides of the border, images complicated stories about gender, race, nationalism, and identity. Playing off stereotypes and a "racial romanticism," to use Catherine Cocks's term, postcards and pamphlets visually represented and contested the borderline as a racial line. ${ }^{17}$ Consider the ways the border town of Douglas, Arizona, sought to define itself as the "gateway to Mexico" in the decade after the Revolution. To negotiate and upend the established visual vocabulary of the dangerous border, the business leaders emphasized a cross-border, cross-race romantic pairing. Photographers and viewers alike thought through the lens of these mixed gendered and racialized images.

In Mexico, photographers, photographs, and their audiences drew on and crafted a different narrative of the Revolution. And, after the revolution came to a close, photographic collections became central to the process of national identity formation. Especially powerful in shaping the public understanding of the nation, photographs of the Mexican Revolution originated as embedded political and social documents. Indeed, John Mraz argues, modern visual

I5. See albums in Harold C. Wayte Photograph Collection, Arizona Historical Society, Tucson. Camp Nogales was renamed Camp Stephen D. Little in late I9I5. Other albums include: Leonard G. Coop Photograph Album, Briscoe Center for American History, University of Texas, Austin; Oliver Taft Hazelton, [Mexican Border Photo Album], 1916, Texas Forces Museum, University of North Texas Libraries, The Portal to Texas History, texashistory.unt.edu/ark:/6753I/metapth743517/.

16. Claire F. Fox offers an especially salient reading of Cal Osbon's version of this image in Fox, "Local and Global on the Same Picture Plane," The Fence and the River: Culture and Politics at the U.S.-Mexico Border (Minneapolis: University of Minnesota Press, 1999), 79-8I.

17. Catherine Cocks, "The Welcoming Voice of the Southland: American Tourism across the U.S.-Mexico Border, 1880-1940," in Benjamin H. Johnson and Andrew R. Graybill, eds., Bridging National Borders in North America: Transnational and Comparative Histories (Durham: Duke University Press, 2010), 227. 


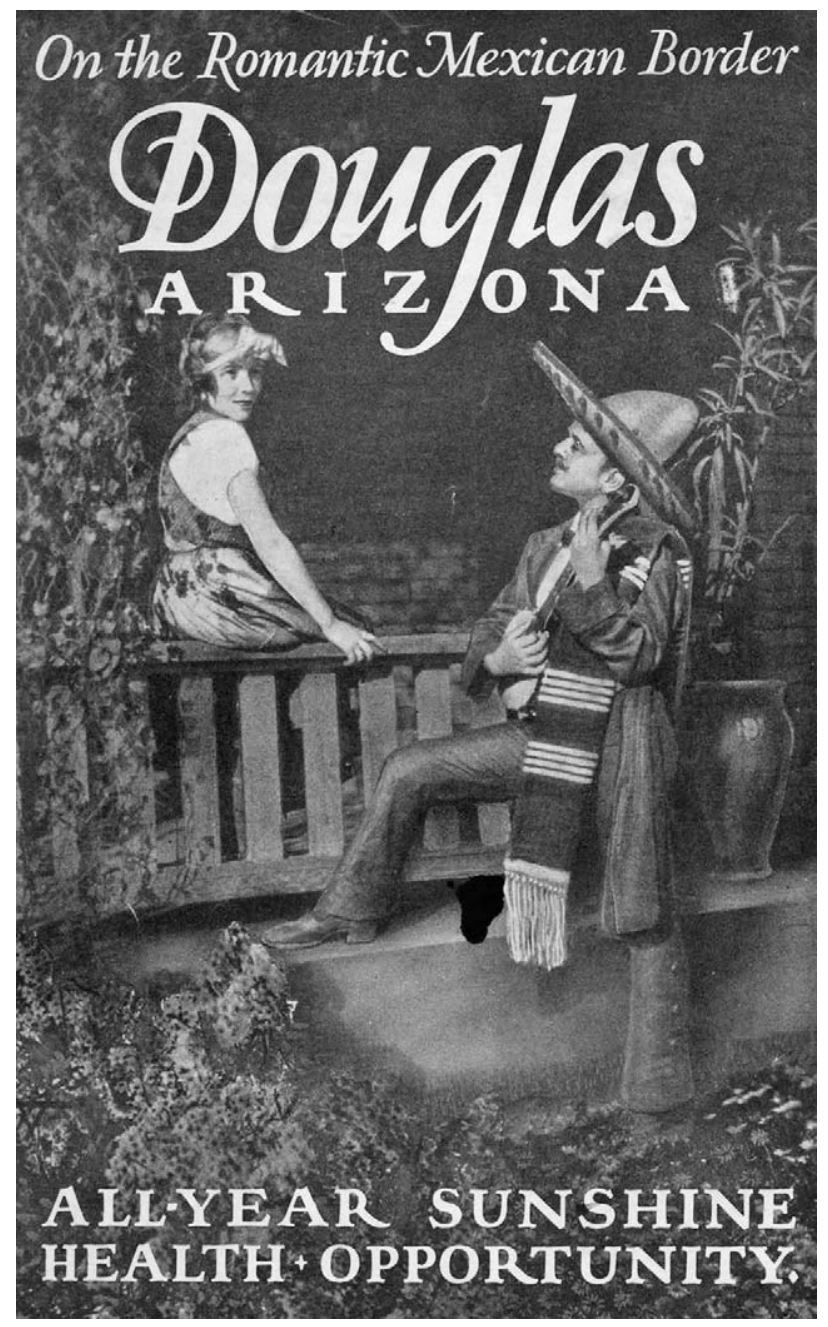

figure 7. Borderland Climate Club, "On the Romantic Mexican Border, Douglas, Arizona," Pamphlet, Douglas, Arizona, [I925]. Courtesy of University of Arizona Libraries, Special Collections.

culture is "the site where Mexican identities have been constructed, deconstructed, and reconstructed." 18

While American and other foreign photographers, alongside Mexican photographers, captured scenes during the Revolution, Mexico City photographers

I8. Mraz, Looking for Mexico, 2. 
and photo agencies worked to capture their distribution. The photographers associated with Casasola Fotográfico (and later known as Agencia Mexicana de Información Fotográfica), the photo agency that Agustin Casasola founded with his brother Miguel, not only took their own photographs, they also relied on regional photographers for images. Sharing and, in some cases, plagiarizing images taken by other photographers was a common practice. In today's archives, the same photographs can be found, but signed by and attributed to different photographers. ${ }^{19}$

Revolutionary-era images distributed through Mexican illustrated magazines, such as La Semana Illustrada, tended to focus on specific leaders, symbols, and events, often artistically posed. Editors, like the photographers, worked to define the political interpretation of the revolutionary conflict. The perspective from Mexico City and the political affiliations of the photographers influenced the various Mexican photographers' portrayal of the Revolution. So too did the proximity of events. La Decena Trágica, the ten tragic days in February 1913 that marked the overthrow of Francisco Madero's government, emphatically brought the revolution into the city and into focus. ${ }^{20}$ Widely distributed photographic postcards of street scenes during and after the scattered violence, shaped both collective and individual memories. Angela, who penned a note onto one of Félix Miret's photo postcards, connected the events to a shared personal history, reminding the receiver that when they lived nearby, they had traveled this road.

During the revolutionary decade, the Mexican photographers and press paid less attention to the northern border imagery than did their U.S. counterparts. Francisco "Pancho" Villa, whose image and story figured prominently in newsreels, images, and imaginations north of the border, was less celebrated visually in central Mexico. After the war, however, Villa became one of the iconic images of the revolution. Consider, for example, the massive collection of images that have become known as the Casasola Archive. Beginning in I92I, it was the basis of picture histories-those visual histories of the nation crafted for both literate and illiterate Mexican citizens-

19. Olivier Debroise, Mexican Suite: A History of Photography in Mexico (Austin: University of Texas Press, 200I), I80. George M. Gugelberger describes the process by which the same photographs ended up in both the Casasola Collection and that of photographer Sabino Osuna; Mexico at the Hour of Combat: Sabino Osuna's Photographs of the Mexican Revolution, ed. Ronald H. Chilcote (Laguna Beach, Cal.: Laguna Wilderness Press, 20I2).

20. Julia Banwell, "Death and Disruption in the Photography of the Decena Trágica," Mexican Studies/Estudios Mexicanos 30 (Winter 2014): IO4-2I. 


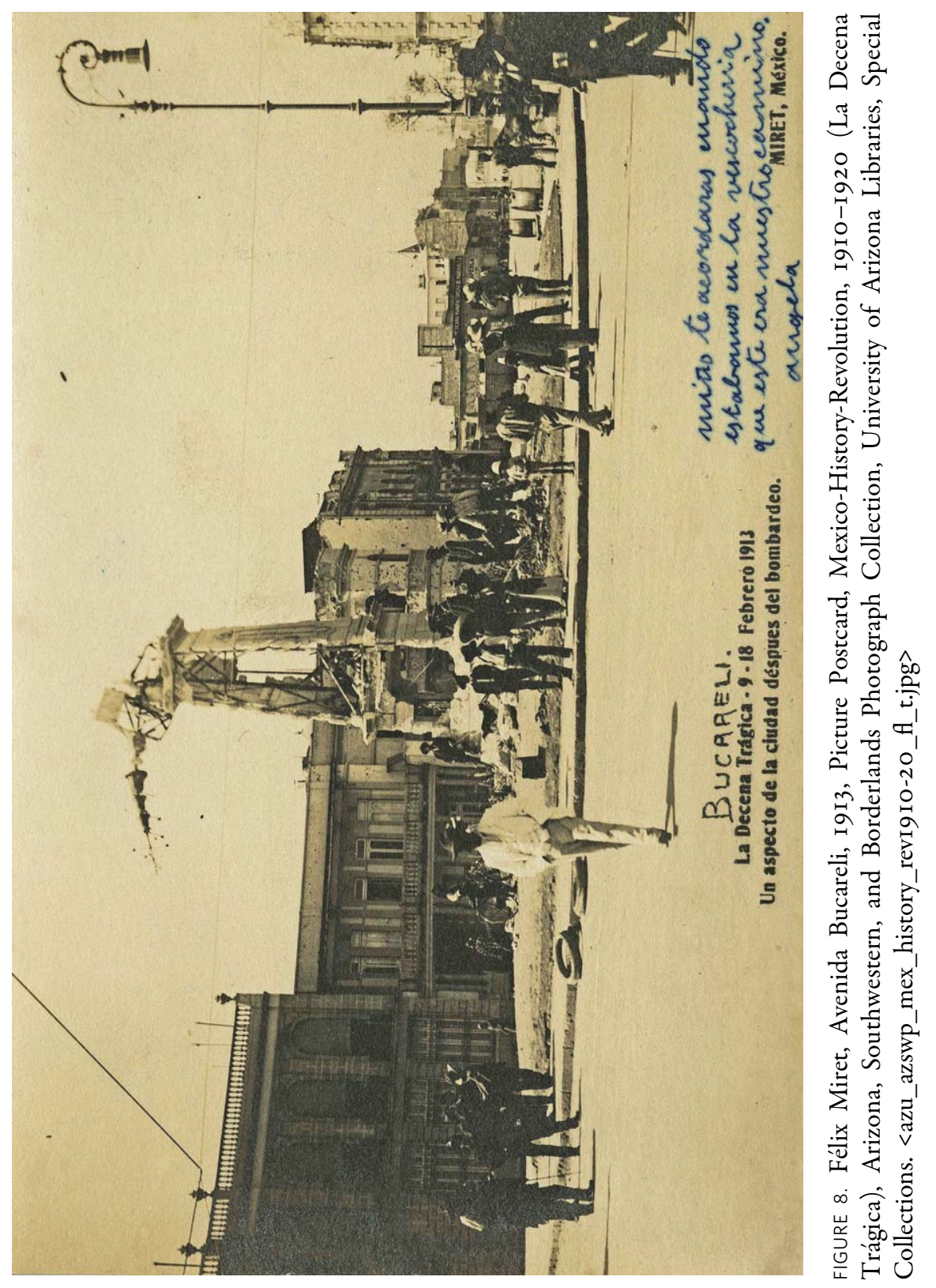




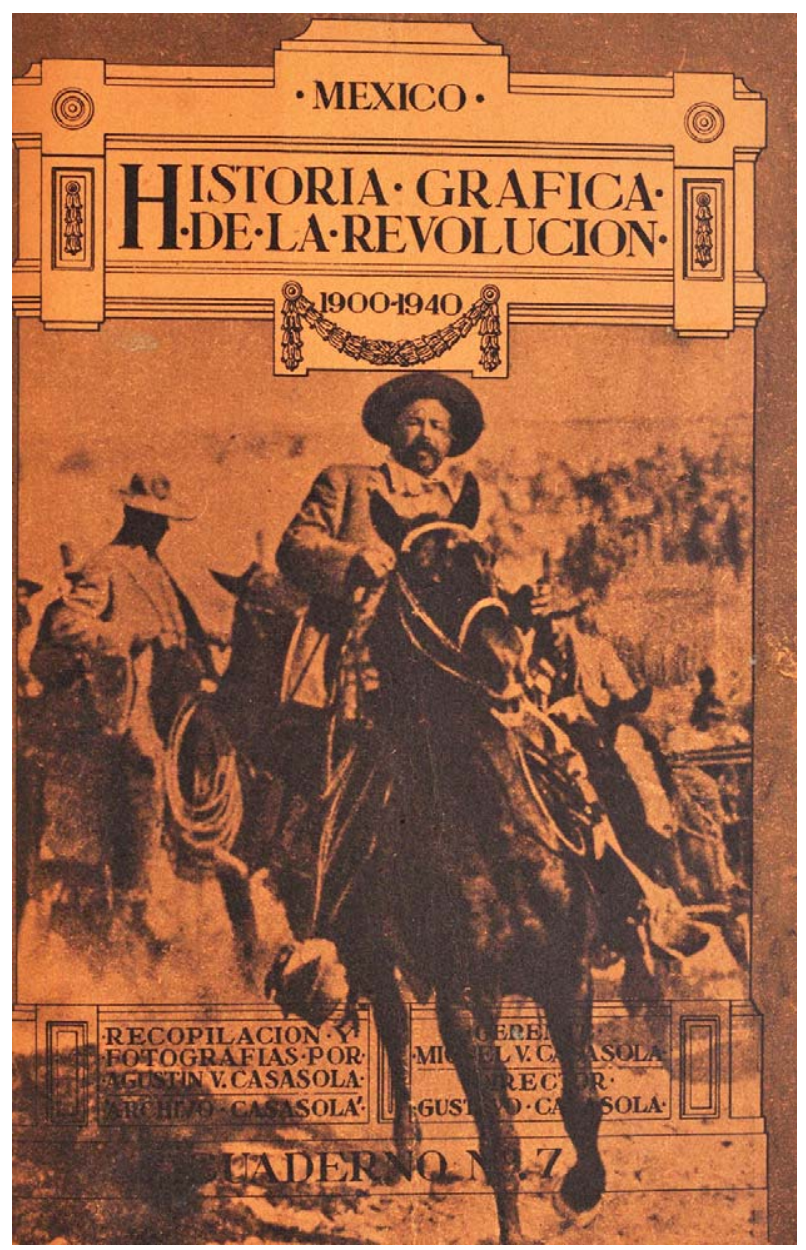

figure 9. Gustavo Casasola, Historia gráfica de la Revolución, 1900-1940, Issue No. 7, cover (México, D.F: [Archivo Casasola, I940]). Courtesy of University of Arizona Libraries, Special Collections.

including the multi-volume Histórica gráfica de la revolución mexicanas that went through multiple printings and editions. ${ }^{21} \mathrm{~A}$ nostalgic and picturesque past to be sure, the visual history of Mexico told through these volumes is one

21. John Mraz, "Picturing Mexico's Past: Photography and Historia Gráfica," South Central Review 2I (Fall 2004): 24-45; John Mraz, "Photographing Mexico," Mexican Studies/Estudios Mexicanos I7 (Winter 200I): I93-2II. See also John Mraz, "Representing the Mexican Revolution: Bending Photographs to the Will of Historica Gráfica," in Photography and Writing in Latin America: Double Exposures, eds. Marcy E. Schwartz and Mary Beth Tierney-Tello (Albuquerque: 
that became especially powerful in representing the visual vocabulary of Mexicanidad and the public perception of the Revolution. ${ }^{22}$ The attention is not on the borderline but on the emergence of a nation, with an emphasis on political leaders and official acts. Purchased by the Mexican government in the 1976, the archive, which includes the photographic works of almost five hundred photographers, is now part of the Fototeca Nacional del Instituto Nacional de Antropología e Historia. ${ }^{23}$

Some of these photographs have, in the decades since their creation, become iconic representations both within and outside of Mexico. A few you might recognize: the revolutionary leaders-Francisco "Pancho" Villa and Emiliano Zapata - at the Presidential Palace in December 19I4; the female figure on the train variously named Adelita; the classic pose of Emiliano Zapata adorned with sombrero, two crossed bandoliers, general's sash, and sword. ${ }^{24}$ As ubiquitous photographs, they are now deployed for purposes well beyond their original intents. The same can be said about these two overlapping visualization projects-for U.S. audiences of the Mexican Revolution through the inflection of the borderline and for Mexican audiences of the construction of the nation through the Revolution. While the projects employed some of the same iconography and images, the different emphases and placement within the narratives point to their malleability.

Let's return now to Humphrey, the plant ecologist, and his visualization project. As you'll recall, he began his repeat photographic series in the I930s-retaking photographs at the same places as earlier nineteenth- or twentieth-century photographers, and using the images to compare vegetative change over time. He was watching dramatic ecological changes taking place.

University of New Mexico Press, 2006), 2I-39; Roberto Tejada, National Camera: Photography and Mexico's Image Environment (Minneapolis: University of Minnesota Press, 2009), esp. 28-4I.

22. John Mraz, Photographing the Mexican Revolution: Commitments, Testimonies, Icons (Austin: University of Texas Press, 20I2); Debroise, Mexican Suite; Ignacio Gutiérrez Ruvalcaba, "A fresh look at the Casasola Archive," History of Photography 20 (3, I996): 19I-95; John Mraz, "Photographers of the Mexican Revolution: The Myth of the Casasolas," Review: Literature and Arts of the Americas, 43 (I, 2010): 46-50.

23. Instituto Nacional de Antropología e Historia, http://mediateca.inah.gob.mx/repositorio/

24. For thoughtful analyses on the iconization of these images see, Andrea Noble, "Photography, Memory, Disavowal: The Casasola Archive," in Images of Power: Iconography, Culture and State in Latin America, eds. Jens Andermann and William Rowe (New York: Berghahn Books, 2005), I95-216; John Mraz, "Zapata and Salinas, Mexico, I9II and I99I," in Getting the Picture: The Visual Culture of the News, eds. Jason E. Hill and Vanessa R. Schwartz (London: Bloomsbury, 2015), 38-40; Andrea Noble, Photography and Memory in Mexico: Icons of Revolution (Manchester, U.K.: Manchester University Press, 201I). 
The severe droughts of the I930s and 1950s especially confounded scientists. What were their causal factors? Seeking answers in the historical record, Humphrey and other natural scientists turned to travelers' accounts, naturalists' surveys, and government records. Coming across the International Boundary Survey's I89os published reports and album, he recognized their value for making comparisons over time. He began to make it a point to stop at every boundary marker he could locate, and, using the I89os photographs as guides, take photographs at the same place. The extensive number and regularity of the monuments are what made these photographs valuable for Humphrey, since they "were usually spaced at intervals of from one to three miles and are easily located, they constitute an excellent source of material for showing graphically the changes that have taken place during the last sixty years." ${ }^{25}$ While the original photographs intended their viewers to focus on the monument, Humphrey and other repeat photographers draw attention to its surroundings - both to the vegetation depicted in the image and to the paired twin photograph from the I89os. The erased temporal space between the two implies a causal connection that explains any differences. In Humphrey's usage, history, in the form of visual documentation, both written and photographic, offers an unbroken line to follow.

In crafting his border visualization project, Humphrey was part of an international community of botanists and field scientists who examined photographs as faithful records, seeking factual knowledge incidental to the original photographers' intents. ${ }^{26}$ Like the physical specimens collecting tradition from which it derives, photographing to measure vegetation change had come to be regarded as an essential scientific practice, especially for ecologists. ${ }^{27}$

25. Robert R. Humphrey, "The Desert Grassland: A History of Vegetative Change and an Analysis of Causes," Botanical Review XXIV (April 1958): 193-252 (also printed, under the same title, as Bulletin 299, Agricultural Experiment Station, University of Arizona, Tucson, 1958), quotation from 217; Humphrey, 90 Years and 535 Miles; Robert R. Humphrey Photograph Collection, Special Collections, University of Arizona Library, Tucson.

26. Robert H. Webb, Diane H. Boyer and Raymond M. Turner, Repeat Photography: Methods and Application in the Natural Sciences (Washington, D.C.: Island Press, 2010).

27. My thanks to Steve Buckley for conversations on these points. See, for examples, Forrest Shreve Photograph Collection, AZ 5I8, Special Collections, University of Arizona Library, Tucson, and the photography of Homer L. Shantz, http://uairarizona.edu/item/274074. Robert E. Kohler, Landscapes and Labscapes: Exploring the Lab-field Border in Biology (Chicago: University of Chicago Press, 2002), I24-32; Nicholas Jardine, James A. Secord and Emma C. Spary, eds., Cultures of Natural History (Cambridge: Cambridge University Press, 1996); Anna Pavord, The Naming of Names: The Search for Order in the World of Plants (New York: Bloomsbury Press, 2005); Frieda Knobloch, "Flora," in Douglas Cazaux Sackman, A Companion to American Environmental History (Malden, Mass.: Wiley-Blackwell, 2010), 327-44. 


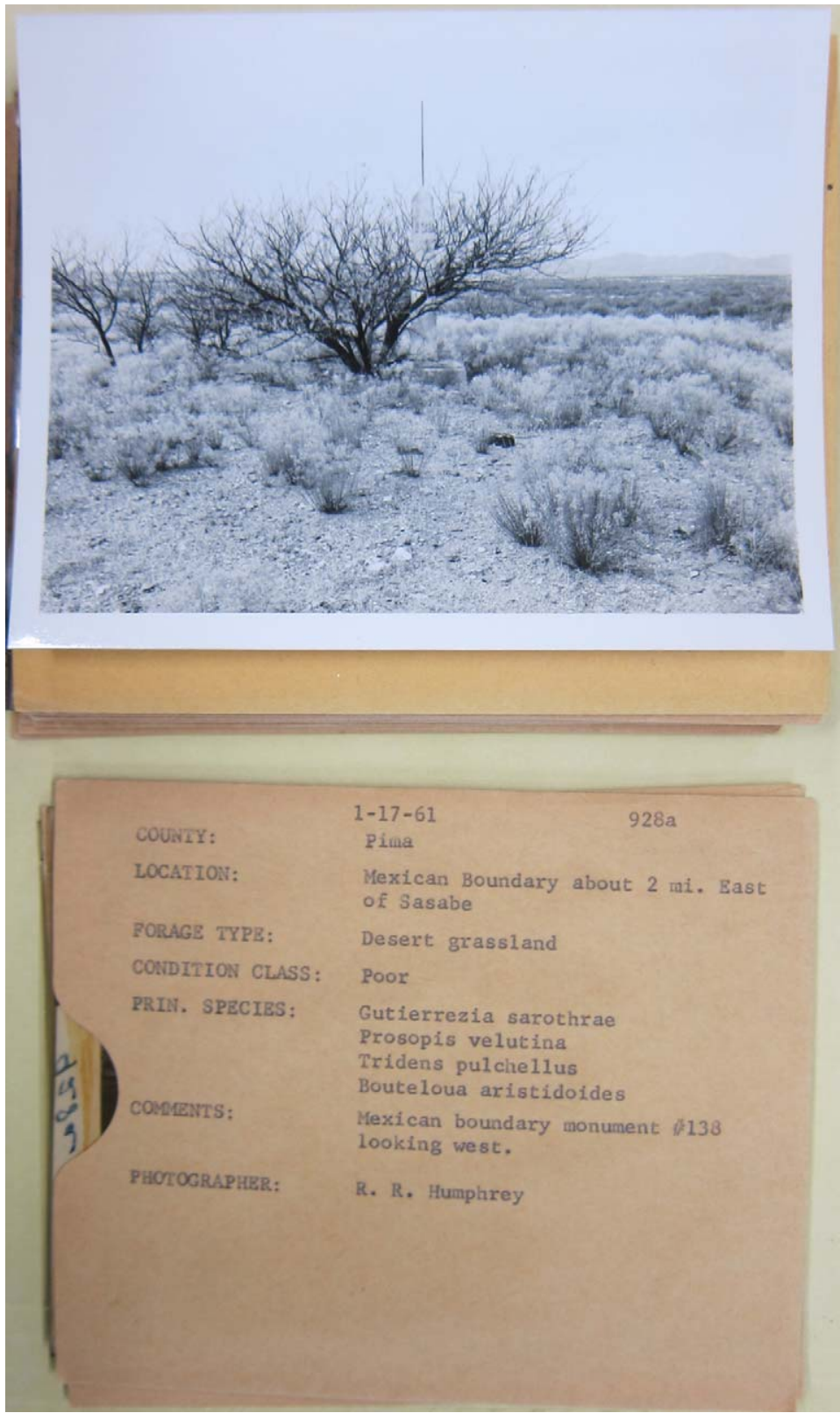

FIgURE 10. R. R. Humphrey, "Pima, Mexican Boundary about 2 mi. East of Sasabe," Box 2, folder 5, MS 43I, Robert Humphrey Photograph Collection, University of Arizona Libraries, Special Collections. 
But these constituted archives of border photographs are more than a scientific tool, a form of measurement, and markers of change, they are also cultural documents and part of a global imaginary. As an arid land scientist, Humphrey, like his predecessors and contemporaries-including Edgar Mearns who collected along the borderline as part of the I89os resurveys, and the peripatetic Robert Forbes who compared African and Arizona deserts-studied desert nature as a global ecological phenomenon. Collecting and describing species in the world's deserts, they envisioned a global imaginary, with ecological, not political borders. ${ }^{28}$ The borderline and its meaning, of course, still echo through the project and sometimes in unexpected ways.

Humphrey returned to the border monument photographs in the 1980 s. Now retired and in his late seventies, he continued to pursue fieldwork with his wife Roberta in the Sonoran Desert. Their repeat photography project mimics that of the original album, with a page dedicated to each monument in New Mexico and Arizona. Humphrey juxtaposes each I89os image with one of his own photographs, taken from the same direction. Although the photographs are of uneven quality, he adds field notes and plant identifications to clarify the scientific view. In his text, Humphrey even imagines himself in the role of the I89os survey men, offering parallels between his own project and theirs. He escaped potential close calls with drug runners and "a Mexican bandido and alleged murderer ... at large in the area," and was conducted to obscure and dangerous locations by U.S. border agents, just as the 1890 os survey teams worried over possible encounters with the outlaw "Apache Kid" and relied on the protection of U.S. military personnel. In some photographs, his carefully positioned Volkswagen bus replaces the horse-drawn wagon shown in the I89os counterparts. Although he might imagine his repeat photography process as a means to isolate extraneous evidence from view, as a scientific tool to measure change over time, his work is embedded in the disruptions of his present.

Humphrey's concerns over safety, his unconscious erasure of the joint labors of the U.S. and Mexican survey team members, and his self-presentation are part of the personal, cultural, and historical contexts of his visualization project. So, too, are his ecological questions and analyses and his global comparative framing. The archives he creates, based on his interpretation of the past, are

28. Katherine G. Morrissey and Marcus Burtner, "Desert Transits and the Global Imaginary: U.S. Arid Lands Scientists at Home and Abroad," paper for the Global Deserts: Environmental History in Arid Lands Conference September I3-I5, 2015, Tucson, Ariz. 


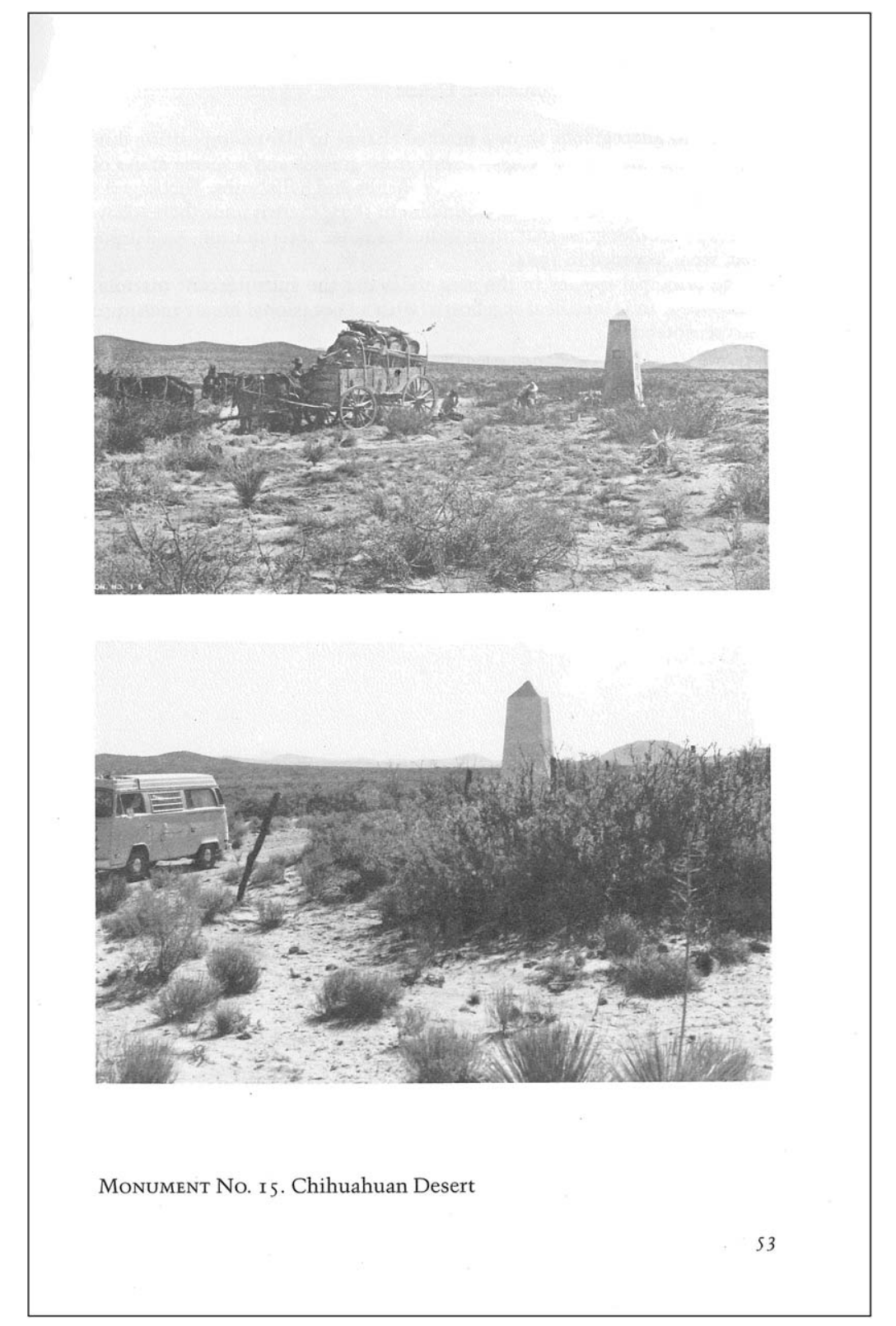

FIGURE 11. Robert R. Humphrey, 90 Years and 535 Miles: Vegetative Change Along the Mexican Border (Albuquerque: University of New Mexico Press, I987), p. 53. 
intended for the future, "to serve as a $1983-84$ historical record for future similar comparative studies." ${ }^{29}$ And the work continues-by government agency scientists on both sides of the border. ${ }^{30}$ The U.S. Geological Survey in collaboration with the Centro de Investigación Científica y de Educación Superior de Ensenada maintain collections of thousands of repeat photographs from camera stations on both sides of the border. The regional collaboration, supported by an international Memorandum of Understanding, enables scientific and technical cooperation in the earth sciences. ${ }^{31}$

Humphrey's decidedly scientific endeavor has also inspired similar artistic cataloging of the border monuments. Photographer David Taylor pays homage to Humphrey's book and project in Monuments (2015) and Working the Line (2010). Like his predecessor, Taylor traveled the borderline, often in company of border agents, to take a photograph of every monument for a different artistic and political purpose. Twenty-three years before Taylor, another photographer, Peter Goin, did the same for Tracing the Line: A Photographic Survey of the Mexican-American Border (1987). Re-envisioning the boundary monument album as well as re-photographing the monuments for their own purposes, Humphrey, Taylor, and Goin deliberately construct historically informed collections. ${ }^{32}$

To end where we began: images of bodies on the border suggest a few other border visualization projects. Other twentieth-century photographers,

29. Humphrey, 90 Years and 535 Miles, 282, 429. In thinking about the potential of repeat photography and rephotographic projects I have been influenced by the work of Mark Klett, Third Views, Second Sights: A Rephotographic Survey of the American West (Albuquerque: Museum of New Mexico Press, 2004). See also James R. Swenson, "The Rephotographic Survey Project and the Landscape of Photography," Ph.D. diss., University of Arizona, 2009.

30. Other plant ecologists who have taken up where Humphrey stopped include James Rodney Hastings and Raymond M. Turner, The Changing Mile: An Ecological Study of Vegetation Change with Time in the Lower Mile of an Arid and Semiarid Region (Tucson: University of Arizona Press, 1965); Raymond M. Turner, Robert H. Webb, Janice E. Bowers and J. R. Hastings, The Changing Mile Revisited (Tucson: University of Arizona Press, 2003); see also Mitch McClaren's rephotography work on the Santa Rita Experimental Range, https://cals.arizona.edu/srer/photos.html.

3I. U.S. Department of State, "Memorandum of Understanding between the United States of America and Mexico, Signed at Reston and Mexico, April 24 and May 2, 2007," Treaties and Other International Acts Series 07-502.I; Robert H. Webb, et al., "The Desert Laboratory Repeat Photography Collection-An Invaluable Archive Documenting Landscape Change," US Geological Survey Fact Sheet, 2007-3046.

32. Claire Carter and Daniel Arreola, David Taylor: Monuments (Reno: Radius Books/Nevada Museum of Art, 2015); David Taylor, Working the Line (Santa Fe: Radius Books, 2010); Peter Goin, Tracing the Line: A Photographic Survey of the Mexican-American Border (Reno: University of Nevada Press, 1987). In 2017, Getty Images photographer John Moore is engaged in a similar assignment. 


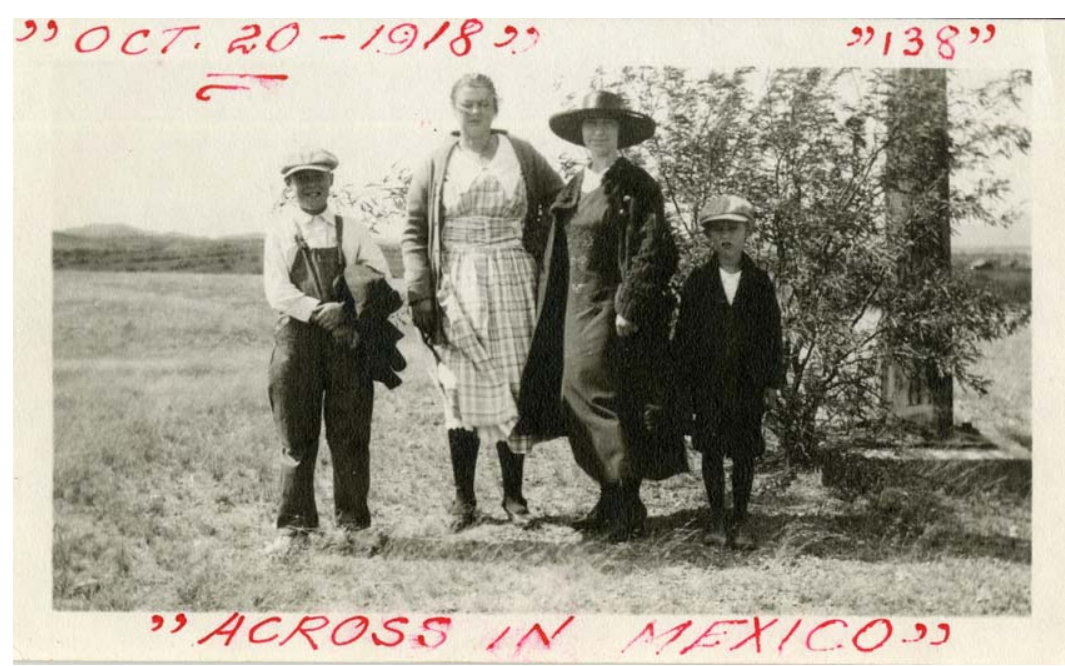

figure 12. "Across in Mexico," [I930s], \#27,559, Contzen Photo Collection, PC23, Arizona Historical Society Library, Tucson.

both amateur and professional, have captured portraits of themselves, others, and boundary monuments with their cameras. Consider, for example, the photograph snapped of Arizona resident Philip Contzen, standing erectly in Nogales alongside monument number I22. The informal snapshot is included in his private papers, now sorted and organized at the Arizona Historical Society Library. ${ }^{33}$ Contzen saved his monument portrait; indeed, it was not the only one in his collection. And it is with another Contzen border monument image I would like to end. The photograph does not center on the monument itself. Instead, Contzen's family members are front and center, arrayed amid desert trees and vegetation. And there, just off to the right, hidden behind people and bushes, is monument number 138 . Its top lopped off by the photo's framing, and its base obscured, the marker is recognizable to those familiar with the form. Underscored by the words "Across in Mexico," the border monument defines the location and the subjects' relation to the borderline. The written labels on the snapshot's front and back also suggest that the monument site was an intended part of the photograph in a more personal way. Contzen lists the names of critical figures in view: Buzzie, Mary, Freddie, Aunt Bridget, and 138.

33. Contzen Family Manuscript Collection, MSi7o, and Contzen Photo Collection, PC23, Arizona Historical Society Library, Tucson. 
What do we make of the semi-visible monument and its familial place? As for other visualization projects, the personalization of the space offers tantalizing, if inconclusive, clues to its meanings. In their public, political, and scientific guises as well, border photographs constitute unstable archives, continually reshaped, re-photographed, and reimagined. There are other bodies on the border, other visualization projects. Some are state-sponsored, involved in the visual control of immigration and immigrants. Others are individual and personal, politicized and public, such as Paseo de Humanidad/Parade of Humanity by the cross border artist collective, Taller Yonke, on the border fence in Nogales. All these representations of the frontera offer traces that can help us to recognize the simultaneous instability and power of borders and, perhaps, to reframe current border visualization projects.

KATHERINE MORRISSEY is associate professor of history at the University of Arizona. 